Old Dominion University

ODU Digital Commons

English Faculty Publications

English

2003

\title{
Eighteenth-Century British Circulating Libraries and Cultural Book History
}

Edward Jacobs

Old Dominion University, ejacobs@odu.edu

Follow this and additional works at: https://digitalcommons.odu.edu/english_fac_pubs

Part of the Cultural History Commons, English Language and Literature Commons, and the Reading and Language Commons

\section{Repository Citation}

Jacobs, Edward, "Eighteenth-Century British Circulating Libraries and Cultural Book History" (2003). English Faculty Publications. 26. https://digitalcommons.odu.edu/english_fac_pubs/26

\section{Original Publication Citation}

Jacobs, E.H. (2003). Eighteenth-century British circulating libraries and cultural book history. Book History, 6(1), 1-22. doi: 10.1353/ bh.2004.0010

This Article is brought to you for free and open access by the English at ODU Digital Commons. It has been accepted for inclusion in English Faculty Publications by an authorized administrator of ODU Digital Commons. For more information, please contact digitalcommons@odu.edu. 


\section{PROJECT MUSE}

\section{Eighteenth-Century British Circulating Libraries and Cultural Book History}

Edward H. Jacobs

Book History, Volume 6, 2003, pp. 1-22 (Article)

Published by Johns Hopkins University Press

DOI: 10.1353/bh.2004.0010

$\Rightarrow$ For additional information about this article http://muse.jhu.edu/journals/bh/summary/v006/6.1jacobs.html 


\title{
EighteENTH-CENTURY BRITISH Circulating LibRARIES AND Cultural Book History
}

\author{
N
}

\author{
Edward Jacobs
}

Circulating library catalogs offer one of the most revealing views available of book publishing and reading in eighteenth-century Britain, since those catalogs and the libraries they document were put together by book traders whose livelihood depended upon giving an unprecedentedly wide range of British readers the books they wanted. ${ }^{1}$ Of course, the perspective on eighteenth-century British book culture provided by their catalogs is nowhere near as comprehensive as the Eighteenth-Century Short Title Catalog (ESTC) or the recently published first volume of The English Novel I770I829: A Bibliographical Survey of Prose Fiction Published in the British Isles (TEN), which "seeks to list all novels of the period whether or not surviving in extant copies, their publication and pricing details, and contemporary review information." 2 As James Raven's "Historical Introduction" to TEN (I 5-I 2I) testifies, such comprehensive bibliographies allow for unprecedentedly authoritative insights into a vast array of issues, ranging from broad facts (such as which titles were most often reprinted) to details (such as relations between individual publishers and printers). Yet we need to remember that retrospective bibliographies, however comprehensive, cannot sufficiently represent book culture as a living culture, with complex local variations and behavioral peculiarities. By contrast, precisely 
because circulating library catalogs and the libraries they bespeak were put together at specific times by specific traders for readers in specific places, they capture the lived particularity of book culture better than probably any other source. ${ }^{3}$

This essay seeks to illustrate the value of balancing comprehensive, retrospective bibliographies and statistics with more localized sources like circulating library catalogs by setting TEN alongside an analysis of the works of fiction listed in the catalogs of Thomas Lowndes (London, c. I766) and Michael Heavisides (Darlington, I790). The libraries of both Lowndes and Heavisides endured for more than thirty years, so presumably they were vital enough parts of their local cultures to represent their relations to books with relative accuracy. Yet these libraries also represent two distinct aspects of the circulating library institution, differing in the scale, composition, location, date, and relative stability of their enterprises.

Based in London, Lowndes ran one of the earliest, largest, and most successful circulating libraries in Britain, operating continuously from I75I until the early I780s, when his son succeeded to the business. ${ }^{4}$ Published circa I 766, fifteen years after Lowndes's library opened, his catalog captures the fiction trade at the end of the "rise" of the formally realistic, didactic novel centered around Samuel Richardson. It lists 6,290 titles (including I,I 32 plays), of which only around Io percent are fiction. However, both in size and percentage of fiction, Lowndes's catalog is typical of the surviving catalogs of Samuel Fancourt (I748), William Bathoe (I757), and John and Francis Noble ( 1767 ), who along with Lowndes constituted the "first generation" of large libraries that began to flourish from the I740s in London. ${ }^{5}$ Lowndes was also a major publisher of plays and fiction, being responsible, for instance, for Frances Burney's first novel, Evelina (I778). Like Lowndes (and the Noble brothers), most eighteenth-century circulating librarians who also published books in significant numbers operated in London. ${ }^{6}$

Heavisides opened his small, 466 -title circulating library in 1784 in provincial Darlington, just north of the border between Yorkshire and County Durham. By this time he was also working as a printer, copperplate press engraver, binder, stationer, and bookseller. In I 790 he issued the catalog of his library, but twelve years later he went bankrupt: the Newcastle Chronicle of 23 January I 802 advertised the sale of "all his Printing and Bookbinding materials" but not (significantly) his stock of books. By I 805 he was back in business both as a librarian and printer in Darlington and worked there until he again went bankrupt "about I8II." In I 8 I 8 he resurfaced in nearby Newcastle as a bookseller and circulating librarianhaving evidently given up on printing, binding, and engraving - and worked as such until at least I $82 \mathrm{I}$. 
That Heavisides evidently did not sell his books after his first bankruptcy and that he abandoned his presses for the librarian-bookseller trade after his second one suggest the centrality of the library to his multifaceted livelihood. The vitality of his enterprise is also underscored by the fact that, despite the two bankruptcies, he did manage to run a circulating library for at least twenty-eight of the thirty-seven years between I784 and I82I, and on his initial trial stayed in business for nearly two decades. Moreover, just as Lowndes typifies the "first generation" of large circulating librarianpublishers who flourished mainly in London from the I740s, Heavisides typifies the provincial librarians who during the last two decades of the century operated small shops devoted heavily to fiction, and who, if they printed or "published" books at all, did so for a local market rather than for the "national" market achieved by major London librarian-publishers like Lowndes. ${ }^{8}$ The 1790 catalog of Heavisides's Darlington library offered readers 466 titles, of which 90 percent were fiction. These figures are roughly equivalent to the average of 430 titles and 70 percent fiction among the extant catalogs of smaller libraries, whose preference for fiction may have been influenced by William Lane's offer to franchise his Minerva Circulating Library. ${ }^{9}$ The date and locale of Heavisides's library were also typical of these smaller libraries, all of which were provincial and all of which issued catalogs between I790 and I $804 .{ }^{10}$ As the earliest of these and the one with the highest percentage of fiction, Heavisides's catalog shows us the fiction trade on the cusp of its late eighteenth-century upsurge, when Gothic novels and other alternative genres began to challenge the Richardsonian novelistic canon captured by Lowndes's catalog. ${ }^{11}$

Considered as different samples of fiction culture, the two catalogs suggest several facts about eighteenth-century British publishing and reading that TEN's comprehensiveness and retrospection overlook, or at least marginalize. First, the fiction in the catalogs foregrounds publishers who also ran circulating libraries as a discrete and historically significant subset of fiction publishers. More specifically, these catalogs suggest that as circulating libraries became a major force in fiction publishing during the last third of the century, they not only increasingly specialized in works that bore the banner of femininity, but did so in ways that powerfully constructed femininity as an "author function" for fiction. ${ }^{12}$ Second, titles common to these catalogs emphasize that, especially after the rise of circulating libraries, titles endured and became popular in ways that cannot be captured by measuring print runs or number of editions, as TEN does. Finally, and most broadly, setting these two catalogs alongside TEN underscores the need to recognize that statistical-bibliographical and cultural history are two different, complementary ways of studying the past. 


\section{Circulating Library Publishing and the Emergence of Feminine Writing}

In eighteenth-century Britain, circulating librarians were widely recognized as a distinct subset of publishers. ${ }^{13}$ The location of circulating librarians who published books itself foregrounded their corporate identity, since they tended to be situated in the West End or other places besides St. Paul's Churchyard and Paternoster Row, where booksellers had traditionally concentrated their shops. ${ }^{14}$ Both publicity by circulating library publishers and reviews and other social commentary on fashionable novels specifically associated circulating library publishers with down-market merchandise and with female authors and readers. ${ }^{15}$ Despite its comprehensiveness, TEN cannot accurately test this reputation, for two reasons. First, it does not mark or analyze ownership of a circulating library as an aspect of publisher identity. Second, it approaches the problematic border between authorial anonymity and authorial gender from a factual rather than a historicist perspective.

There are certainly good reasons why TEN, like ESTC, does not mark circulating libraries as a subset of publishers. The project subdivides publishers by no other criteria, except for the obviously pertinent and title-pageaccessible one of place of operation. And to have cross-matched publishers in TEN with the circulating library owners in Robin Alston's Library History Database ${ }^{16}$ while the bibliography was in process would have been a major complication. But the fact remains that by not coding circulating library publishers as a group, TEN overlooks a significant aspect of eighteenthcentury British print culture. ${ }^{17}$ As a first step toward harvesting what TEN can reveal about circulating library publishing, I offer a list of the publishers in TEN's "Index of Booksellers and Printers" whose names, locations, and periods of operation match circulating librarians from Alston's Library History Database. ${ }^{18}$ This list can be much more fully exploited than I have been able to do in this essay, but even the minimal analysis it offers underscores the importance of circulating libraries as publishers of fiction. For circulating librarians had a hand in more than 80 percent of the I,42I works of fiction listed in TEN and in most cases bore sole or primary responsibility for the publication.

In order to analyze accurately the perception within eighteenth-century fiction culture that circulating library publishers and women were connected, one needs not only to recognize that circulating librarians published books, but also to approach anonymous authorship in a different way than TEN does. TEN classifies works that were anonymously genderedbeing, according to their title pages, "by a lady" or "by a gentleman" - as 
anonymous (TEN, 45 n. 95). By contrast, I classify such works as a subset of their respective genders (Tables $\mathrm{I}-2$ ).

Authorial anonymity was certainly an ambivalent state in eighteenthcentury Britain. Raven notes that anonymity was sometimes exposed by reviews or by references on title pages to other works by the author (TEN, $4 \mathrm{I}-43$ ), and circulating library catalogs also occasionally give their patrons "inside" information on authorship. For instance, the edition that Lowndes stocked of Eliza Haywood's The Husband: In Answer to the Wife (T. Gardner, 1756) was published anonymously, and his edition of The Wife (T. Gardner, I756), which Haywood also wrote, was pseudonymically anonymous, its title page declaring it to be "By Mira, one of the authors of the female spectator, and Epistles for ladies." Most readers acquainted with fiction could derive Haywood's authorship from these teasing clues. But just in case they could not, Lowndes's catalog banks on Haywood's fame, violating its alphabetical ordering near the end of its list of octavo novels to read:

I990. Wife, by Mrs. Haywood

I991. Husband, by ditto, in Answer to the Wife

In such cases of "blown" anonymity, it seems equally justifiable to classify the works as anonymous or authorial. But in principle, to classify as anonymous works whose title pages declare them to be "by a lady" or "by a gentleman" occludes the ways that actual eighteenth-century readers perceived those works and their authorship. Such works were anonymous in the sense that they connected themselves to no individual. On the other hand, these works were even more gendered to eighteenth-century readers than works that named female or male authors, precisely because an epithet like "by a lady" minimized personal identity in favor of a corporate, gendered identity.

For various reasons, it is difficult to translate TEN's categorization of anonymously gendered works into the categorization I have followed. ${ }^{19}$ However, the 737 works of fiction in the catalogs of Lowndes and Heavisides constitute a significant sample of eighteenth-century fiction, being slightly over half the I,42I works in TEN and covering a much broader time span than I770-99. ${ }^{20}$ And the fiction from these catalogs indicates that during the last third of the eighteenth century, as circulating-library publishers radically increased their market share, they also increasingly specialized in anonymously feminine works. Hence, among publishers, they were disproportionately responsible for the ways anonymously gendered works constructed feminine gender as an "author function" in late eighteenth-century British culture. 
Table I. Quantitative comparison of circulating library publishers vs. noncirculating library publishers of the works of fiction with recoverable imprints listed in the I766 catalog of Thomas Lowndes's Circulating Library.

\begin{tabular}{|c|c|c|c|c|c|c|c|c|}
\hline & $\begin{array}{l}\text { Anon. } \\
\text { Authors }\end{array}$ & $\begin{array}{l}\text { Female } \\
\text { Named }\end{array}$ & $\begin{array}{l}\text { Female } \\
\text { Anon. }\end{array}$ & $\begin{array}{c}\text { Female } \\
\text { Total }\end{array}$ & $\begin{array}{l}\text { Male } \\
\text { Named }\end{array}$ & $\begin{array}{l}\text { Male } \\
\text { Anon. }\end{array}$ & $\begin{array}{l}\text { Male } \\
\text { Total }\end{array}$ & Totals \\
\hline Publications by & $31[65 \%]$ & $3[100 \%]^{*}$ & 0 & $3[6 \%]$ & $12[86 \%]^{*}$ & $2[14 \%] *$ & $14[29 \%]$ & 48 \\
\hline $\begin{array}{l}17 \text { circulating } \\
\text { library publishers }\end{array}$ & $15 \%$ & $6 \%$ & - & $5 \%$ & $9 \%$ & $17 \%$ & $10 \%$ & $12 \%$ \\
\hline $\begin{array}{l}\text { Contemporaneity } \\
\text { index totals } \\
\text { (index = catalog date } \\
\text { minus book date) }\end{array}$ & 470 & 21 & 0 & 21 & 185 & 27 & 212 & 703 \\
\hline $\begin{array}{l}\text { Contemporaneity } \\
\text { index averages }\end{array}$ & 15.2 & 7.0 & - & 7.0 & 15.4 & 13 & 15.1 & 14.7 \\
\hline $\begin{array}{l}\text { Publications by } \\
229 \text { noncirculating } \\
\text { library publishers }\end{array}$ & $\begin{array}{l}171 \\
85 \%\end{array}$ & $\begin{array}{l}45[79 \%]^{*} \\
94 \%\end{array}$ & $\begin{array}{l}12[21 \%]^{*} \\
100 \%\end{array}$ & $\begin{array}{l}57[16 \%] \\
95 \%\end{array}$ & $\begin{array}{l}118[92 \%]^{*} \\
91 \%\end{array}$ & $\begin{array}{l}10[8 \%]^{*} \\
83 \%\end{array}$ & $\begin{array}{l}128[36 \%] \\
90 \%\end{array}$ & $\begin{array}{l}356 \\
88 \%\end{array}$ \\
\hline $\begin{array}{l}\text { Contemporaneity } \\
\text { index totals }\end{array}$ & 4,771 & 1,279 & 292 & 1,571 & 6,228 & 220 & 6,448 & 12,784 \\
\hline $\begin{array}{l}\text { Contemporaneity } \\
\text { index averages }\end{array}$ & 27.9 & 28.4 & 24.3 & 27.6 & 52.8 & 22.0 & 50.4 & 35.9 \\
\hline $\begin{array}{l}\text { Total publications } \\
\text { by } 246 \text { publishers }\end{array}$ & $202[50 \%]$ & $48[80 \%]^{*}$ & $12[20 \%]^{*}$ & $60[15 \%]$ & $130[92 \%]^{*}$ & $12[8 \%]^{*}$ & $142[35 \%]$ & 404 \\
\hline $\begin{array}{l}\text { Cumulative total, } \\
\text { comtemporaneity indices }\end{array}$ & 5,241 & 1,300 & 292 & 1,592 & 6,437 & 247 & 6,684 & 13,487 \\
\hline $\begin{array}{l}\text { Cumulative average, } \\
\text { contemporaneity indices }\end{array}$ & 25.9 & 27.1 & 24.3 & 26.6 & 49.5 & 20.6 & 47.1 & 33.4 \\
\hline
\end{tabular}

* Percentages of the gender subtotals, not of the total for this publisher type.

Percentages in italics represent the proportions of publications within a given authorial category issued by circulating library publishers and noncirculating library publishers. 
Table 2. Quantitative comparison of circulating library publishers vs. noncirculating library publishers of the works of fiction with recoverable imprints listed in the 1790 catalog of Michael Heavisides's Circulating Library.

\begin{tabular}{|c|c|c|c|c|c|c|c|c|}
\hline & $\begin{array}{l}\text { Anon. } \\
\text { Authors }\end{array}$ & $\begin{array}{l}\text { Female } \\
\text { Named }\end{array}$ & $\begin{array}{l}\text { Female } \\
\text { Anon. }\end{array}$ & $\begin{array}{c}\text { Female } \\
\text { Total }\end{array}$ & $\begin{array}{l}\text { Male } \\
\text { Named }\end{array}$ & $\begin{array}{l}\text { Male } \\
\text { Anon. }\end{array}$ & $\begin{array}{l}\text { Male } \\
\text { Total }\end{array}$ & Totals \\
\hline $\begin{array}{l}\text { Publications by } \\
37 \text { circulating } \\
\text { library publishers }\end{array}$ & $\begin{array}{l}85[68 \%] \\
42 \%\end{array}$ & $\begin{array}{l}7[26 \%]^{*} \\
26 \%\end{array}$ & $\begin{array}{l}20[74 \%]^{*} \\
49 \%\end{array}$ & $\begin{array}{l}27[22 \%] \\
40 \%\end{array}$ & $\begin{array}{l}11[85 \%]^{*} \\
20 \%\end{array}$ & $\begin{array}{l}2[15 \%] * \\
20 \%\end{array}$ & $\begin{array}{l}13[10 \%] \\
21 \%\end{array}$ & $\begin{array}{l}124 \\
36 \%\end{array}$ \\
\hline $\begin{array}{l}\text { Contemporaneity } \\
\text { index totals } \\
\text { (index = catalog date } \\
\text { minus book date) }\end{array}$ & 1,207 & 88 & 136 & 224 & 145 & 24 & 169 & 1,600 \\
\hline $\begin{array}{l}\text { Contemporaneity } \\
\text { index averages }\end{array}$ & 13.9 & 12.6 & 6.8 & 8.3 & 13.8 & 12.0 & 15.0 & 12.9 \\
\hline $\begin{array}{l}\text { Publications by } \\
123 \text { noncirculating } \\
\text { library publishers }\end{array}$ & $\begin{array}{l}115[55 \%] \\
58 \%\end{array}$ & $\begin{array}{l}20[49 \%]^{*} \\
74 \%\end{array}$ & $\begin{array}{l}21[51 \%]^{*} \\
51 \%\end{array}$ & $\begin{array}{l}41[20 \%] \\
60 \%\end{array}$ & $\begin{array}{l}44[85 \%]^{*} \\
80 \%\end{array}$ & $\begin{array}{l}8[15 \%]^{*} \\
80 \%\end{array}$ & $\begin{array}{l}52[25 \%] \\
79 \%\end{array}$ & $\begin{array}{l}208 \\
64 \%\end{array}$ \\
\hline $\begin{array}{l}\text { Contemporaneity } \\
\text { index totals }\end{array}$ & 2,183 & 331 & 272 & 603 & 1,479 & 246 & 1,725 & 4,453 \\
\hline $\begin{array}{l}\text { Contemporaneity } \\
\text { index averages }\end{array}$ & 19.0 & 16.6 & 13.0 & 14.7 & 33.6 & 30.8 & 33.2 & 21.4 \\
\hline $\begin{array}{l}\text { Total publications } \\
\text { by } 160 \text { publishers }\end{array}$ & $199[60 \%]$ & $27[40 \%]^{*}$ & $41[60 \%]^{*}$ & $68[20 \%]$ & $56[85 \%]^{*}$ & $10[15 \%]^{*}$ & $66[20 \%]$ & 333 \\
\hline $\begin{array}{l}\text { Cumulative total, } \\
\text { comtemporaneity indices }\end{array}$ & 3,349 & 419 & 408 & 827 & 1,665 & 270 & 1,935 & 6,082 \\
\hline $\begin{array}{l}\text { Cumulative average, } \\
\text { contemporaneity indices }\end{array}$ & 16.8 & 15.5 & 10.0 & 12.2 & 29.7 & 27.0 & 29.3 & 18.3 \\
\hline
\end{tabular}

* Percentages of the gender subtotals, not of the total for this publisher type.

Percentages in italics represent the proportions of publications within a given authorial category issued by circulating library publishers and noncirculating library publishers. 
According to Lowndes's catalog, as of 1766 , circulating library publishers contributed minimally to the fiction available to readers, producing only I 2 percent of total publications and constituting only 7 percent of the publishers (Table I). However, they devoted 20 percent more of their total output to anonymous works than other publishers did. And interestingly, at this point, they also preferred male over female works slightly more than other publishers did, putting out Io percent fewer female works and 6 percent more male works than other publishers. Even more interestingly, none of their female works at this point was anonymous, whereas 2 I percent of the female works put out by other publishers were anonymously gendered.

According to Heavisides's catalog, by 1790 circulating libraries had not only increased their market share of fiction by 24 percent, to 36 percent of the total. They had also shifted their resources toward female works - and especially toward anonymously female works-far more pointedly than other publishers had (Table 2). Both the circulating library publishers and other publishers in Heavisides's catalog continued to publish more anonymous than named works. And circulating libraries still devoted a greater percentage of their output to anonymous works than other publishers did, although the margin was now only I I percent, rather than the 20 percent of I766. However, circulating libraries now published twice as many female works as male works, while other publishers still put out more male than female works, though only by a margin of 5 percent (as opposed to the 20 percent margin in Lowndes's catalog). Specifically, between Heavisides's catalog and Lowndes's (Tables I and 2), anonymous works published by circulating libraries were up 3 percent, female ones up I 6 percent, and male works down I 9 percent. Between the two catalogs, anonymous works by noncirculating library publishers were up 7 percent, their female works up 4 percent, and their male works down I I percent. Both groups of publishers thus decreased their percentage of male works, but circulating libraries decreased male works by nearly double the percentage that other publishers did. And whereas other publishers balanced the decrease in male works mainly by producing more anonymous works, circulating libraries shifted from male to female works.

Or rather, I should say, to "feminine" works. For just as, between I 766 and I790, circulating libraries chose, in contrast to other publishers, to shift their resources from fiction declared to be by men to fiction declared to be by women, during this same period they chose anonymous rather than named female works far more often than other publishers did. As Tables I and 2 show, the percentage of female works that were anonymous increased 74 percent among circulating libraries between the two catalogs, as opposed to 30 percent among other publishers. As percentages of total publications, anonymously female works increased I 6 percent among 
circulating libraries, versus 7 percent among other publishers. As percentages both of female works and of total publications, anonymously female works thus increased roughly two and a half times more among circulating library publishers than among others. By contrast, as a percentage of male totals, anonymous works were up I percent among circulating libraries but 7 percent among other publishers, while as a percentage of total publications, anonymously male works were down 2 percent among circulating libraries but up I percent among others.

There are several possible explanations for why anonymously female fiction became a "trademark" of circulating library publishers during the decades when those publishers became major players in the fiction trade. Economic and cultural circumstances made circulating library publishers and female authors, especially novice ones, mutually attractive to each other, and circulating library publicity pointedly recruited manuscripts from women. ${ }^{21}$ Yet if female authors more often approached circulating libraries than other publishers, the female authors who published with circulating libraries may have insisted on anonymity more often than women who published with other traders, since circulating libraries were more disreputable than other publishers, being routinely condemned for crass pandering to fashionable taste and for poor workmanship. ${ }^{22}$ It may also be that many of these anonymously feminine works were by men, but that circulating libraries, and/or their authors, strategically marketed them as feminine. ${ }^{23}$ But however many of the anonymously feminine works published by circulating libraries were actually by men, the fact remains that during the last third of the eighteenth century, circulating library publishers effaced personal identity in favor of feminine identity far more often than other publishers did, and to a far greater extent than either they or other publishers hid personal identity behind masculinity. Hence, insofar as anonymously feminine fiction contributed to making femininity a highly visible - and contested - aspect of eighteenth-century British society, circulating library publishers were disproportionately responsible for this.

The cultural construction of femininity by circulating libraries was intensified by two more precise factors. First, circulating libraries historically concentrated their production of such fiction far more than other publishers did. Second, they played the pioneering role in a fifteen-year cycle of anonymously feminine fiction publishing that was twice repeated, from I 770 to I 784 and again from I785 to I799.

Based on the anonymously feminine epithets indexed by TEN, Raven's "Historical Introduction" observes that for "reasons not entirely clear, authors resorted to this [anonymously feminine] style with particular enthusiasm in the late I780s, when overall publication of fiction began a marked growth" (42). More specifically, as my Table 3 shows, 58 percent 
of the anonymously feminine fiction in Heavisides's catalog that was published I770-90, and 35 percent of such fiction indexed by TEN I770-99, was published between I 785 and $\mathrm{I} 789 .{ }^{24}$ That such a high percentage of anonymously female fiction was published in this five-year span surely intensified the cultural foregrounding of femininity as a corporate authorial identity, and contributed to a sense of what Raven calls "the march of the woman novelist" (TEN, 49). Yet as Table 3 also indicates, circulating libraries published much more of their total anonymously female output between I785 and I789 than did other publishers, I 5 percent more in Heavisides's catalog and I9 percent more in TEN. For both data sets, this means that circulating libraries produced slightly more than 60 percent of the anonymously female fiction published during this watershed half-decade. Consequently, insofar as circulating libraries were, as I argued above, a recognized subculture of fiction publishers in late eighteenth-century Britain, the high concentration of anonymously female fiction between I785 and I 789 not only increased the visibility of "feminine" fiction and femininity, but also constructed feminine fiction as the particular stock-in-trade of circulating library publishers.

This association in the late $\mathrm{I} 78$ os between anonymously female fiction and circulating libraries was also underscored by a fifteen-year cycle in the publication of such fiction that was repeated twice from I 770 to I 799 (Table 3). From both I 770 to I 784 and I 785 to I 799 , this cycle had three five-year stages. The first stage of both cycles saw the largest percentage of total anonymously female publications for the cycle, ranging from 22 percent during $1770-74$ to 58 percent during $1785-89$ in Heavisides, and from I 5 percent during $I 770-74$ to 35 percent during $1785-89$ in TEN. Despite the lower raw percentages of the total given by TEN for these first stages, in both TEN and the Heavisides data the first stage of the second cycle, from I 785 to I 789 , saw roughly 2.5 times more anonymously feminine publications than the first stage of the first cycle. More important, circulating libraries claimed between 6I percent and 63 percent of the total anonymously female publications during this first stage, regardless of whether the stage was I $770-74$ or $1785-89$, and whether one uses the data from Heavisides's catalog or from TEN. During the second stage of each cycle, the percentage of anonymously female publications dropped, and the market share of circulating libraries dropped even more, to a minimum of o percent for $1775-79$ in Heavisides. During the third stage, the percentage of anonymously female works remained more or less the same as in the second stage, but circulating libraries and other publishers had roughly equal market shares. These two methodologically distinct data sets suggest that, in two fifteen-year cycles from I770 to I799, circulating libraries during an initial five-year span pioneered what Raven calls an "enthusiasm" 
Table 3. Anonymously female works of fiction from Michael Heavisides's I 790 Circulating Library Catalog and from The English Novel I770-1829: A Bibliographical Survey (TEN).

\begin{tabular}{|c|c|c|c|c|c|c|}
\hline & \multicolumn{3}{|c|}{ Heavisides } & \multicolumn{3}{|c|}{ TEN } \\
\hline & $\begin{array}{l}\text { Circulating } \\
\text { Library } \\
\text { Publishers }\end{array}$ & $\begin{array}{c}\text { Other } \\
\text { Publishers }\end{array}$ & Total & $\begin{array}{l}\text { Circulating } \\
\text { Library } \\
\text { Publishers }\end{array}$ & $\begin{array}{c}\text { Other } \\
\text { Publishers }\end{array}$ & Total \\
\hline $1770-74$ & $\begin{array}{l}5[63 \%] \\
25 \%\end{array}$ & $\begin{array}{l}3[37 \%] \\
19 \%\end{array}$ & $\begin{array}{c}8 \\
22 \%\end{array}$ & $\begin{array}{l}13[62 \%] \\
20 \%\end{array}$ & $\begin{array}{l}8[38 \%] \\
11 \%\end{array}$ & $\begin{array}{l}21 \\
15 \%\end{array}$ \\
\hline $1775-79$ & $\begin{array}{l}0 \\
0 \%\end{array}$ & $\begin{array}{l}2[100 \%] \\
12 \%\end{array}$ & $\begin{array}{l}2 \\
6 \%\end{array}$ & $\begin{array}{l}1[7 \%] \\
2 \%\end{array}$ & $\begin{array}{l}13[93 \%] \\
17 \%\end{array}$ & $\begin{array}{l}14 \\
10 \%\end{array}$ \\
\hline 1780-84 & $\begin{array}{l}2[40 \%] \\
10 \%\end{array}$ & $\begin{array}{l}3[60 \%] \\
19 \%\end{array}$ & $\begin{array}{c}5 \\
14 \%\end{array}$ & $\begin{array}{l}8[50 \%] \\
12 \%\end{array}$ & $\begin{array}{l}8[50 \%] \\
11 \%\end{array}$ & $\begin{array}{l}16 \\
11 \%\end{array}$ \\
\hline $1785-89$ & $\begin{array}{l}13[62 \%] \\
65 \%\end{array}$ & $\begin{array}{l}8[38 \%] \\
50 \%\end{array}$ & $\begin{array}{l}21 \\
58 \%\end{array}$ & $\begin{array}{l}30[61 \%] \\
45 \%\end{array}$ & $\begin{array}{l}19[39 \%] \\
26 \%\end{array}$ & $\begin{array}{l}49 \\
35 \%\end{array}$ \\
\hline $1790-94$ & & & & $\begin{array}{l}4[19 \%] \\
6 \%\end{array}$ & $\begin{array}{l}17[81 \%] \\
23 \%\end{array}$ & $\begin{array}{l}21 \\
15 \%\end{array}$ \\
\hline $1795-99$ & & & & $\begin{array}{l}10[53 \%] \\
15 \%\end{array}$ & $\begin{array}{l}9[47 \%] \\
12 \%\end{array}$ & $\begin{array}{l}19 \\
14 \%\end{array}$ \\
\hline Total & $20[56 \%]$ & 16 [44\%] & 36 & $66[47 \%]$ & $74[53 \%]$ & 140 \\
\hline
\end{tabular}

Percentages in italics represent the proportion of the total for that column. 
for anonymously female works (TEN, 42). Other publishers appropriated this fashion during the next five years, and during the third phase the two groups achieved a sort of equilibrium - at least until circulating libraries started the second, more intense cycle of competition over fiction that identified itself with femininity, rather than with individuals or with nobody.

As Raven notes (TEN, 42), it is difficult to say with any certainty why the fashion for anonymously female fiction bubbled in $1785-89$ and, less intensely, in $1770-74$. The earlier wave might be connected to the fact that by 1770 most of the canonical male novelists were dead, creating the need for some new "generic" fashion within the fiction trade. Insofar as the second wave foregrounded and specified the corporate identity of women, it surely interacted with what Laura Brown calls the "feminization of ideology" and thus with late eighteenth-century feminism..$^{25}$ Both cycles probably also have much to do with the practical need, mentioned above, of circulating library publishers to develop and exploit their own new "stable" of authors and "brands" of fiction. And, significantly, both Heavisides's catalog and TEN suggest that the most famous - or notorious - circulating librarianpublishers of their times were preeminently responsible for initiating the two cycles of fashion for anonymously female fiction (Tables 4 and 5).

Table 4. Publishers of anonymously female works of fiction I770-74 and I78 5-89 from Michael Heavisides's I790 Circulating Library Catalog.

$$
\text { 1770-74 }
$$

\begin{tabular}{lclc} 
Circulating Libraries & Number & Other Publishers & Number \\
\hline Bell \& Etherington & 1 & Baldwin & 1 \\
Boosey & 1 & Newberry, F. \& Smith & 1 \\
Nobles & 2 & Nicoll, W. & 1 \\
Vernor \& Chater & 1 & & \\
\hline 4 & 5 & 3 & 3
\end{tabular}

1785-89

\begin{tabular}{lclc} 
Circulating Libraries & Number & Other Publishers & Number \\
\hline Allen & 1 & Bew \& Symonds & 1 \\
Hookham & 5 & "The Booksellers" & 1 \\
Lane & 7 & Byrne, Wogan, et al. [Dublin] & 1 \\
& & Dilly & 1 \\
& & Price, White, et al. [Dublin] & 1 \\
& & Robinsons & 1 \\
& & White \& Son [London] & 1 \\
& & Whitestone \& Byrne [Dublin] & 1 \\
\hline 3 & 13 & 8 & 8
\end{tabular}


Of the anonymously female fiction indexed by TEN (Table 5), Thomas Lowndes, the Noble brothers, and John Roson between them produced 62 percent of the circulating library share of such works from I770 to I774. Lowndes and Roson did not produce any of the anonymously female books published I770-74 in Heavisides's library, but the Nobles did 40 percent of them (Table 4). During the second, larger bubble of anonymously female works, from $\mathrm{I} 785$ to $\mathrm{I} 789$, William Lane and Thomas Hookham between them produced an even greater majority of the circulating library share, accounting for 73 percent in TEN and 92 percent in Heavisides. By contrast, according to TEN, George Wilkie, the only noncirculating library

Table 5. Publishers of anonymously female works of fiction $1770-74$ and 1785-89 from The English Novel 1770-I 829: A Bibliographical Survey.

$1770-74$

\begin{tabular}{lclc} 
Circulating Libraries & Number & Other Publishers & Number \\
\hline Boosey & 1 & Baldwin & 1 \\
Chater \& Vernor & 1 & Becket \& De Hondt & 1 \\
Fuller, J. & 1 & Bew & 1 \\
Lowndes & 3 & Bladon & 1 \\
Nobles & 3 & Newberry, F. & 1 \\
Riley & 1 & Nicoll & 1 \\
Roson & 2 & Wilkie & 2 \\
Jones, T. \& B. & 1 & & \\
\hline 8 & 13 & 7 & 8
\end{tabular}

1785-89

\begin{tabular}{lclc} 
Circulating Libraries & Number & Other Publishers & Number \\
\hline Abraham & 1 & Axtell & 1 \\
Allen & 3 & Baldwin, R. & 3 \\
Geary & 1 & Barker, J. & 1 \\
Hookham & 8 & Dilly \& Wilkie & 1 \\
Lane & 14 & Flexney & 1 \\
Lowndes & 2 & Johnson, J. & 1 \\
Swift & 1 & Kearsley & 1 \\
& & Logographic Press & 2 \\
& & Richardson, W. & 2 \\
& & Robinsons & 2 \\
& & Sleator & 1 \\
& & Strahan \& Cadell & 1 \\
& & Wilkie & 1 \\
\hline 7 & & Wilkins & 1 \\
\hline
\end{tabular}


publisher to produce more than one anonymously female work from I770 to $\mathrm{I} 774$, produced only two, or 25 percent of the noncirculating library share. Similarly, Richard Baldwin, the leading noncirculating library publisher of anonymously female fiction from I 785 to I 789 , produced only I 6 percent of their share.

One might therefore suppose that the trend was the brainchild of a few specific traders, rather than of circulating library publishers as a group, who shared common business interests and strategies. On the other hand, different circulating library publishers started the two trends: Lowndes and the Nobles the first time, and Hookham and Lane the second time. And as Raven's survey of major publishers stresses, within eighteenth-century British culture, Hookham and Lane were widely recognized as the "successors" to the circulating library tradition of "dedicated novel publishing" pioneered by the Nobles and Lowndes. ${ }^{26}$ Hence, whatever local or practical concerns motivated these two generationally distinct sets of book traders to cultivate the same fashion fifteen years apart, these fashions forged yet another link in the cultural chain tying anonymously female fiction-and hence, as I argued above, femininity itself - to the circulating library institution.

\section{Modes of Popularity in the Circulating Library Age}

Like many other projects, TEN estimates popularity in terms of how quickly and how often a title was republished (TEN, Tables 3-5). Because manifest reader demand drove republication, whereas initial publication was based on speculation about demand, republication data is certainly a logical way to measure which works the most readers wanted, and for relatively how long. However, republication data tends to measure only what I would like to call "canonical popularity," for two reasons. In the first place, the titles foregrounded by republication data were popular mainly among people who wanted-and could afford - to buy books. No doubt the demand of circulating libraries for rental copies often contributed to the decision to republish works. But because one or two rental copies of most works were all most circulating libraries needed, libraries' demand for rental copies surely motivated republication less than did the expectation of other sales, whether wholesale to traders interested in bulk, or retail sales to individuals in bookshops. In the second place, the popularity revealed by republication data appears only from the relatively long-term view afforded by hindsight. This is not to deny the importance of recognizing works that 
continued to be printed for decades, even centuries. But republication data alone cannot situate those works within the historical moments in which their various editions participated.

On the other hand, as what I have styled "slices" of lived culture, circulating library catalogs can put works that hindsight identifies as canonically popular into historical and cultural context. For instance, catalogs can often reveal what edition of a work was in a particular library, and which books it was shelved alongside. ${ }^{27}$ Perhaps more important, analyzing works common among different circulating library catalogs - and especially works that turn up frequently in catalogs despite limited or no republicationmeasures an entirely different kind of popularity from canonical popularity, which I propose to call "experiential popularity." As such works remind us, after the advent of circulating libraries, works could remain in circulation, and hence persist as part of the popular "canon," without being republished. This mode of popularity differed culturally, as well as physically, from canonical popularity. For if multiple librarians saw profit in renting available copies of such works when no publisher saw profit in producing more copies of them, then presumably these works were marketable and popular as singular, sometimes casual reading experiences, rather than as possessions and objects of "deep" investment.

The catalogs of Lowndes and Heavisides are, of course, a limited sample of extant circulating library catalogs. However, as I noted at the beginning of this essay, both libraries endured for several decades (in Heavisides's case despite two bankruptcies). As a set, they capture differences in fiction culture not only between I 766 versus I790, but also between large London libraries in which fiction was at best one-fifth of total stock and small provincial libraries in which fiction was three-quarters or more of total stock. The titles common to the catalogs of Lowndes and Heavisides thus logically sketch a popular, "lived" canon of fiction that bridges the historical, geographical, and trade differences between the two libraries. And significantly, within that canon, works of "experiential" popularity have nearly an equal share with works of "canonical" popularity.

Of the twenty-five titles that appear in the catalogs of both Lowndes and Heavisides, ${ }^{28} 40$ percent are canonical British novels that were often republished during the eighteenth century, including Richardson's three novels, Moll Flanders, Tom Jones, The Vicar of Wakefield, Charlotte Lennox's Female Quixote, Henry Brooke's Fool of Quality, and Eliza Haywood's History of Jemmy and Jenny Jessamy and Invisible Spy. However, an equal percentage ( 40 percent) of the titles common to the two catalogs are works that were rarely if ever reprinted, surviving now only in rare book roomsif at all-and being seldom if ever remarked in scholarship. It is certainly surprising that two such different libraries saw profit in offering their readers 
Felicia to Charlotte: Being Letters from a Young Lady in the Country, to Her Friend in Town; The History of Lavinia Rawlins; The History of a Young Lady of Distinction; The Impetuous Lover, or, The Guiltless Parricide; Memoirs of a Man of Pleasure, or, The Adventures of Versorand; Memoirs of Sir Thomas Hughson and Mr. Joseph Williams; The Life and Adventures of Peter Wilkins, a Cornish Man; The Surprises of Love, Exemplified in the Romance of a Day, or, An Adventure in Greenwich-Park, Last Easter; The Widow of the Wood; and The Wise Ones Bubbled. ${ }^{29}$ But the fact that experientially and canonically popular works make up equal shares of the titles common to these catalogs underscores the historiographical logic of balancing the long-term view of popularity given by republication data with the short-term "synchronic" view of popularity afforded by circulating library catalogs and other contemporary sources. For surely the depth of popularity in a particular cultural moment is just as important as the historical length of popularity. The logic of balancing these two measures is further emphasized by the fact that, of the thirty-three titles first published between I 770 and I790 that TEN identifies as having five or more editions before I829-and that Heavisides therefore could have stocked - he only held twelve, or 36 percent. ${ }^{30}$ Limits in Heavisides's expertise or trading connections might account for this relatively low percentage. But it also suggests that many of the works that hindsight identifies as canonically popular were, upon their original publication-or at other moments in the history of their republication-relatively obscure, or at least not so "deeply" popular as the long-term view of their republication implies.

The remaining 20 percent of titles common to the catalogs of Lowndes and Heavisides are translations of Spanish picaresque and rogue fiction. Along with Don Quixote, both libraries stocked The Adventures of Gil Blas, The History and Adventures of Don Alphonso Blas, The Life and Adventures of Lazarillo de Tormes, and the compilation Novellas Españolas by Castillo Solorzano and Pérez de Montalván. All of these titles were republished and retranslated throughout the eighteenth century, and they remind us that translations, especially from French and Spanish, were a popular subset of the eighteenth-century British fiction trade, both canonically and experientially. ${ }^{31}$ And despite the cliché in criticism, then and now, about flimsy circulating library editions being read to pieces in a few months, ${ }^{32}$ in each of these libraries three of these five common picaresque titles were in editions published forty years or more before the date of the catalog. ${ }^{33}$ There are also a surprising number of such "antiquarian" books among the titles specific to each catalog, although they are not a significant percentage of either library's overall stock. Still, both librarians were willing to stock quite old books, and the seventeenth-century romances in folio that 
Lowndes held would be the envy of many twenty-first-century rare book rooms. The fact that Lowndes, like most librarians who held substantial folio collections, did not allow those works to circulate suggests another mode of popularity for fiction in eighteenth-century Britain, which we might call "bibliographical" popularity, the popularity of books as physical objects with an elite status and aesthetic form. Certainly most works that had such popularity also had canonical popularity. But by allowing us to know such details as which editions of works were on the shelves of libraries, circulating library catalogs, in this respect as in those outlined above, allow us to place a lived, cultural context around the canonical popularity revealed by retrospective data on republication.

\section{Balancing Book History}

To argue, as I have in this essay, that circulating library catalogs show us the lived culture surrounding eighteenth-century British books in ways that TEN cannot is by no means to argue that TEN and similarly retrospective approaches to book history are "wrong." Projects like TEN exploit hindsight to recover comprehensive, powerfully objective data about the past, and I hope that I have sufficiently acknowledged my admiration of, and debt to, such knowledge. Yet I also hope that I have indicated how, precisely insofar as such projects seek to recover facts whether or not people at the time knew them, their devotion to factuality tends toward presentism, which needs to be balanced with sources such as circulating library catalogs that more directly represent the past as it appeared to the people who lived in and made it.

\section{Notes}

Several resources available online at http://web.odu.edu/al/engl/faculty/ejacobs.html are cited in this essay and function as effective appendices to it. Publishers of Fiction in the Circulating Library Catalog of Thomas Lowndes (I766) and Publishers of Fiction in the Circulating Library Catalog of Michael Heavisides (I790) list the publishers, short titles, and dates of the works of fiction with recoverable imprints contained, respectively, in the catalogs of Lowndes and Heavisides. Both files separate publishers who also ran circulating libraries from other publishers, and categorize titles according to whether their authors were anonymous, female, or male. Circulating Library Publishers of New British Fiction I770-I799 gives the dates and locations of publishers listed in The English Novel I770-I829: A Bibliographical Survey of Prose Fiction Published in the British Isles, ed. Peter Garside, James Raven, and Rainer Schöwerling, vol. I, I770-I799, ed. James Raven and Antonia Forster, with Stephen Bending (Oxford: Oxford University Press, 2000), who match circulating librarians listed in Robin Alston's Library History Database (http://www.r-alston.co.uk/contents.htm). Fiction Titles 
Common to the Circulating Library Catalogs of Thomas Lowndes (I766) and Michael Heavisides (I790) gives title page transcriptions, imprints, and, where known, authorship of titles that appear in both catalogs.

I would like to thank several people who have assisted me with this project over the years. Elizabeth Harlan edited and reformatted Publishers of Fiction in the Circulating Library Catalog of Thomas Lowndes (I766) and Publishers of Fiction in the Circulating Library Catalog of Michael Heavisides (I790), composed spreadsheets from them that facilitated Table 3, and assisted me in cross-checking them against Robin Alston's Library History Database (http://www.r-alston.co.uk/contents.htm). She also drafted Circulating Library Publishers of New British Fiction I770-I799. Krishna Manavalli did most of the data input and formatting for Publishers of Fiction in the Circulating Library Catalog of Thomas Lowndes (1766). Manuela Mourão generously sacrificed some of her own research time to helping me with the tedious task of verifying the publication details given in Publishers of Fiction in the Circulating Library Catalog of Thomas Lowndes (I766) and Publishers of Fiction in the Circulating Library Catalog of Michael Heavisides (I790).

I. By allowing readers to borrow unlimited numbers of books for an annual subscription fee generally around one guinea, circulating libraries increased the spectrum of British readers who could afford to read books. As Michael Gamer notes in Romanticism and the Gothic: Genres, Reception, and Canon Formation (Cambridge: Cambridge University Press, 2000), 65, circulating libraries also changed the reading habits of existing readers, as, for example, people "who would never have considered buying fiction could borrow it fairly cheaply." Circulating library owners, moreover, became some of the century's most prolific publishers - especially of fiction - starting in the I 74 Os with John and Francis Noble and culminating in the I790s with William Lane's Minerva Press. The major studies of circulating libraries are Paul Kaufman, "The Community Library: A Chapter in English Social History," Transactions of the American Philosophical Society, n.s., 57 (I967): 3-67; Alan McKillop, "English Circulating Libraries, I725-50," Library, 4th ser., I4 (I934): 477-85; Hilda Hamlyn, "Eighteenth-Century Circulating Libraries in England," Library, 5th ser., I (I947): I97-222; and Devendra Varma, The Evergreen Tree of Diabolical Knowledge (Washington: Consortium Press, I972). See also Hamlyn's master's thesis, "The Circulating Libraries of the Eighteenth Century" (London University, I948), whose first appendix provides a list of known circulating libraries, complete with addresses and authorities for their existence. For a current listing, see Robin Alston's Library History Database at http://www.r-alston.co.uk/contents.htm. On publishing by circulating library owners, see Edward Jacobs, Accidental Migrations: An Archaeology of Gothic Discourse (Lewisburg: Bucknell University Press, 2000): I 57-72, and James Raven, "The Noble Brothers and Popular Publishing," Library I2, no. 4 (I990): 293-345. The twenty-two extant catalogs (described in Kaufman) are our only direct evidence about the circulating library institution, since almost no lending registers have survived. For an analysis of one surviving lending record, see Jan Fergus, "Eighteenth-Century Readers in Provincial England: The Customers of Samuel Clay's Circulating Library and Bookshop in Warwick, I770-2," Papers of the Bibliographic Society of America 78, no. 2 (I984): I 5 5-2I3.

2. Peter Garside, "General Introduction," in The English Novel I770-I 829: A Bibliographical Survey of Prose Fiction Published in the British Isles, ed. Peter Garside, James Raven, and Rainer Schöwerling, vol. I, I770-I799, ed. James Raven and Antonia Forster, with Stephen Bending (Oxford: Oxford University Press, 2000), I-2. Hereafter I abbreviate this work as TEN.

3. Sources such as personal reading diaries also give insight into lived book culture, though as records of individual experience they offer little basis for generalization about culture per se. See Raven, "Historical Introduction," TEN, IIO-I3, for a summary of such records that are extant and a bibliography of studies of them. See also Stephen M. Colclough, 
"Procuring Books and Consuming Texts: The Reading Experience of a Sheffield Apprentice, I 798," in Book History 3 (2000): 2I-44.

4. See the Library History Database (http://www.r-alston.co.uk/contents.htm); TEN, 76-77; and Henry R. Plomer, A Dictionary of Printers and Booksellers Who Were at Work in England, Scotland, and Ireland from 1726 to 1775 (London: Bibliographical Society, I968): I 59 .

5. Kaufman, "The Community Library," II-I3, lists the scale and percentage of fiction in the twenty-two extant circulating library catalogs from eighteenth-century Britain. For a critical summary of this evidence, see Kaufman, I4-I9, and Lee Erikson, "The Economy of Novel Reading: Jane Austen and the Circulating Library," SEL 30 (I990): 573-90, esp. 58 O. Among the seventeen catalogs for large libraries, with average holdings of about five thousand titles, only an average of 20 percent was fiction. However, among the five catalogs of smaller libraries, with average holdings of 430 titles, over 70 percent are fiction, a figure corroborated by Fergus, "Eighteenth-Century Readers in Provincial England," which reports that, during I770-72, 72 percent of the eighty-four books borrowed from Samuel Clay's tiny library/ bookstore in Warwick were novels. Other evidence also suggests that the figure for smaller libraries may be more generally accurate. The Use of Circulating Libraries, a I797 how-to manual for proprietors (reprinted in Varma, Evergreen Tree of Diabolical Knowledge, I95-203), recommends 79 percent fiction. Moreover, according to a I798 advertisement by William Lane's Minerva Press Circulating Library, larger libraries may have held as many as "twenty five copies of each modern and approved work" (quoted in Varma, Evergreen Tree of Diabolical Knowledge, 53). Novels probably made up a good proportion of such "modern and approved" titles, and if larger circulating libraries more often stocked multiple copies of novels than of other titles, then the percentage of fiction in their catalogs may underestimate their actual holdings and trade in the genre. One should add that all of the larger libraries not in London date after 1787 , which underscores the fact that large-scale circulating librarieslike publishing by circulating library owners - originated in London during the I740s.

6. Below I use the phrase "circulating library publishers" to describe such book traders, and the title pages of many of their works include phrases such as "printed for John and Francis Noble at their Circulating Library." However, many works by "circulating library publishers" do not thus or otherwise advertise their link to the circulating library run by the person "for" whom the work was printed, probably in order to avoid the stigma increasingly attached to circulating libraries over the course of the century. On this stigma, see John Tinnon Taylor, Early Opposition to the English Novel (New York: King's Crown, I943). To call these or other eighteenth-century book traders "publishers" is of course anachronistic, since at this period "bookseller" was the usual term for those who arranged for the printing of works and held copyrights to them. However, calling this segment of the book trade "publishers" avoids using an inelegantly oxymoronic term like "circulating library booksellers."

7. Christopher J. Hunt, The Book Trade in Northumberland and Durham to I860 (Newcastle: Thorne's Bookshops, I975), 48. Hunt cites no evidence for this second bankruptcy. Many thanks to Barry McKay, Keith Manley, Mrs. Peter Isaac, and Maureen Bell for directing me to the above information in Hunt about Heavisides's business.

8. Although, as noted just below, Heavisides's library was 90 percent fiction, there is no evidence that he ever printed or "published" fiction or other works that aspired to a national distribution. Rather, in keeping with John Feather's generalizations in The Provincial Book Trade in Eighteenth-Century England (Cambridge: Cambridge University Press, I98 5): 47-50, 98-I 2I, Heavisides did mainly "jobbing” printing for his local community. Among his extant publications, the closest thing to a "national-market" book is Charles Rollins's History of the Besieging and Taking of Babylon by Cyrus, \&c. (Darlington: Printed and sold by M. Heavisides, I 800). More typical are Richard Cockerel's An Introduction to Plain Trigonometry... 
Together with a Variety of Questions Interspersed by Way of Exercise (Darlington: Printed and sold by M. Heavisides, for the author, I792), the subtitle of which indicates its status as a school book and/or practical manual; and James Cochrane's Thoughts Concerning the Uses of Clay Marl as Manure (Darlington: Printed and sold by M. Heavisides, I 800), a work of evident local agricultural interest. That only a handful of the works he produced during more than thirty years as a printer have survived also suggests the local appeal and distribution of what he printed.

9. According to Dorothy Blakey, The Minerva Press, I790-I820 (London: Bibliographical Society, I939), by 1784 Lane was offering to supply prospective librarians with "a stock of books from his warehouse" (I8), and it was in 1784 that Heavisides opened his library. However, Lane published only I 2 percent of the fiction in Heavisides's catalog, whereas, according to tables II and I 2 in TEN, during the I780s Lane accounted for 20 percent of the total fiction output, and during the I790s fully 3 I percent. So if Heavisides did avail himself of Lane's franchising offer, he was far from dependent on Lane.

IO. See note 5 above. For reasons of space and unity, I have opted to discuss the evidence about London versus provincial book culture afforded by these catalogs in a separate essay. However, the brunt of this evidence is that provincial circulating libraries significantly magnified the presence within the provincial English book trade of Dublin publishing, Heavisides stocking the "cheap" editions of canonical English novels produced by Dublin "pirates" and by other down-market traders like circulating libraries, far more often than Lowndes.

I I. See Raven, "Historical Introduction," TEN, 2I-56, for data on the upturn in publishing and the role of women and the Gothic genre at the end of the century. For cultural analysis, see Jacobs, Accidental Migrations, I 57-252.

I2. Michel Foucault, "What Is an Author?" in Language, Counter-memory, Practice, trans. Donald F. Bouchard and Sherry Simon (Ithaca: Cornell University Press, I977), II $3-38$.

I3. Taylor, Early Opposition to the English Novel; Jacobs, Accidental Migrations, I 57-252; Raven, "Historical Introduction," TEN, 84-86, 74, 78-80; James Raven, "From Promotion to Proscription: Arrangements for Reading and Eighteenth-Century Libraries," in The Practice and Representation of Reading in England, ed. James Raven, Helen Small, and Naomi Tadmor (Cambridge: Cambridge University Press, I996): I75-20I; Raven, "Noble Brothers," 293-345.

I4. Raven, "Historical Introduction," TEN, 74, 79-80. Cf. James Raven, "Memorializing a London Bookscape: The Mapping and Reading of Paternoster Row and St. Paul's Churchyard, I695-I8I4," in Order and Connexion: Studies in Bibliography and Book History, ed. R. C. Alston (Woodbridge: Boydell \& Brewer, I997): I77-200.

I 5. On advertising by circulating libraries, see Edward Jacobs, Accidental Migrations, I72-74, and "A Previously Unremarked Circulating Library: John Roson and the Role of Circulating-Library Proprietors as Publishers in Eighteenth-Century Britain," Papers of the Bibliographical Society of America 89 (I995): 6I-7I; Raven, "Noble Brothers," 293-345. On the association between circulating libraries, down-market trading, and women, see Jacobs, Accidental Migrations, I59-72, 227-3I; Emma J. Clery, The Rise of Supernatural Fiction (Cambridge: Cambridge University Press, I995), 87-88, 96-98, I35-47; Taylor, Early Opposition to the English Novel; Raven, "Historical Introduction," TEN, I IO, I I 8-2 I.

I6. Robin Alston, Library History Database, http://www.r-alston.co.uk/contents.htm.

I7. Raven's "Historical Introduction" does discuss the careers of the major librarians/ publishers during his survey of important publishers of the period (7I-86), noting their geographic distinctness from other publishers (74) and suggesting that they made their profits in different ways from other publishers $(84-86)$. However, he does not consider them as a subset of publishers in any of his tables or statistical analyses. 
I 8. Circulating Library Publishers of New British Fiction, I770-I799, available online at http://web.odu.edu/al/engl/faculty/ejacobs.html.

I9. According to Raven's Table 6, of the I,390 works in TEN for which we must take the title page claim as it stands - which is 98 percent of total works -73 percent are anonymous, I 5 percent female, and I 2 percent male. By contrast, my categorization of titles from Heavisides's catalog, which is roughly equivalent to the I770-99 time span of TEN, show 60 percent anonymous, 20 percent female, and 20 percent male. Because TEN does index anonymously feminine epithets like "by a lady" as authors, one can adjust its statistical representation of anonymous versus female works. However, the bibliography does not index anonymously male works in the same way, so a full adjustment and analysis is not possible without enormously tedious labor.

20. The data set from these catalogs also correlates with several statistical facts revealed by TEN. Raven's “Historical Introduction" notes that Io percent of titles from the I770-99 period have not survived (2O-2I), which is exactly the percentage of lost works from Heavisides's catalog. See Edward Jacobs and Antonia Forster, "Lost Books and Publishing History: Two Annotated Lists of Imprints for the Fiction Titles Listed in the Circulating Library Catalogs of Thomas Lowndes (I766) and M. Heavisides (I790), of Which No Known Copies Survive," Papers of the Bibliographical Society of America 89 (I995): 260-97, 267-68. As my Table 3 shows, and as I discuss below, TEN and Heavisides's catalog also agree, if more roughly, on the proportions of anonymously feminine fiction published by circulating libraries versus other publishers, and on the historical pattern of publication of such works.

2I. On the economics of circulating library publishing, see Jacobs, Accidental Migrations, I63-74, 228-3 I. On circulating library publicity, see the sources cited in note I 5 above. On Frances Burney and the impetus toward anonymity by female authors, see Cheryl Turner, Living by the Pen: Women Writers in the Eighteenth Century (London: Routledge, I995), esp. 26-4I, 9I-92.

22. Taylor, Early Opposition to the English Novel; Raven, "Historical Introduction," TEN, I03-IO, I I 8-2I; Jacobs, Accidental Migrations, I 59-72, 227-3 I; Clery, Rise of Supernatural Fiction, 95-105; Turner, Living by the Pen, 27-28, 33-34.

23. The anonymously feminine fiction indexed by TEN gives some support to this latter supposition, though the data cannot be taken as conclusive. Of the nine anonymously feminine works published by circulating libraries for which author attribution is possible, three (33 percent) are known to be by men, while only two ( 77 percent) of the attributable anonymously feminine works by other publishers are by men. However, attributable works are in both cases only about I 5 percent of the total anonymously feminine works by the two publisher groups, and as Raven notes (TEN, $4 \mathrm{I}-44$ ), attribution is a tricky business.

24. Raven counts I60 anonymously feminine works among those in TEN (42), but my use of the index leads me to only the I 40 total given in my Table 3 . The index entry for "A Lady" cross-references "Old Woman," "Officer's Daughter," and "Unpatronized Female," but these epithets do not appear in the index, which may at least partially explain our different counts. I have also chosen not to include TEN I798: 60 as anonymously feminine, since it is by Samuel Jackson Pratt, but "Selected by a Lady."

25. Laura Brown, "The Feminization of Ideology: Form and the Female in the Long Eighteenth Century," in Ideology and Form in Eighteenth-Century Literature, ed. David Richter (Lubbock: Texas Tech University Press, I999): 223-40, esp. 237-38. See also Jacobs, Accidental Migrations, 227-35.

26. TEN, 78. Cf. $74-75$ on the Nobles, $76-77$ on Lowndes, $78-90$ on Hookham and Lowndes, and table I2, p. 73, on Roson.

27. Raven's "Historical Introduction" to TEN maintains that the inaccuracy of title indexing by libraries makes such identification dubious (I9, 85). But this judgment ignores 
the fact that nearly every extant circulating library catalog also lists the number of volumes and replacement cost of titles, and many catalogs further specify the printed format of works. Together with what I have myself found to be a quite accurate rendering of title pages in catalogs, these bibliographical specifications in most cases allow one to identify with relative certainty which edition of a work was on the shelf of a library. Fiction Titles Common to the Circulating Library Catalogs of Thomas Lowndes (1766) and Michael Heavisides (I790), available online at http://web.odu.edu/al/engl/faculty/ejacobs.html, identifies six differences in editions among the twenty-five titles common to the catalogs of Lowndes and Heavisides. See also Jacobs, Accidental Migrations, I72-9I, and "Buying into Classes: The Practice of Book Selection in Eighteenth-Century Britain," Eighteenth Century Studies 33 (I999): 43-64.

28. Fiction Titles Common to the Circulating Library Catalogs of Thomas Lowndes (I766) and Michael Heavisides (I790) gives title page transcriptions, imprints, and, where known, authorship of these titles.

29. Of these, Mary Collyer's Felicia to Charlotte and John Cleland's Surprises of Love were reprinted at least once in London, but neither work was anywhere near "canonical" in its time. Other works in this list were not reprinted except, in a few cases, in simultaneous Dublin editions meant mainly for an Irish home market. See Mary Pollard, Dublin's Trade in Books, I 550-I800 (Oxford: Oxford University Press, I989), 66-I09, on the market for socalled Irish "piracies."

30. The pragmatic limitation of TEN to works that were first published or translated I770-99 (Peter Garside, "General Introduction," 4) precludes using it to analyze the popularity of works published earlier that remained in circulation, either through republication before $\mathrm{I} 770$ or through persistence in libraries without republication. See also the following paragraph on "antiquarian" books in libraries.

3 I. Cf. Raven, "Historical Introduction," TEN, 56-65, on translations and translators.

32. See, for example, Taylor, Early Opposition to the English Novel, and Raven, "Historical Introduction,” TEN, I I 8-2 I.

33. See Fiction Titles Common to the Circulating Library Catalogs of Thomas Lowndes (I766) and Michael Heavisides (I790). For Lowndes, these are the I652 and I687 editions of Don Quixote and the I708 edition of Lazarillo de Tormes. For Heavisides, they are the I749 edition of Gil Blas, the I74I edition of Don Alphonso Blas, and the I747 edition of Novellas Espanollas. I should note that these "antiquarian" works illustrate both the virtue and limitations of the "contemporaneity index" measure used and defined in Tables I and 2 of this essay and in the two online resources listing the publishers of fiction in the catalogs of Lowndes and Heavisides. This measure has the virtue of identifying the relative age of the actual books on the shelves of circulating libraries, but it fails to capture the relative age of the works themselves. 